ISSN: 2362-1303 (Paper) | eISSN: 2362-1311(Online)

\title{
Determinants of Profitability in Nepal Oil Corporation
}

\author{
Ghanshyam Prasad Shah ${ }^{1}$ \&Prof. Dr. Radhe Shyam Pradhan ${ }^{2}$ \\ ${ }^{1} \mathrm{PhD}$ Scholar, Mewar University, Chittorgarh, Rajasthan, India \\ ${ }^{2}$ Professor (Management Faculty), Tribuvan University, Nepal
}

\section{Corresponding Author}

Ghanshyam Prasad Shah

ghanshyampd.shah@gmail.com

\begin{abstract}
Profitability is the primary goal of all business organization. Without profitability the business will not survive in the long run. So measuring current and past profitability is very important. Profitability is measured by income and expenses where as income is generated from the activities of the business. This study aims to analyze the microeconomic and macroeconomic factors of profitability in the context of Nepal Oil Corporation. Regression analysis was used to determine the determinants of profitability. The results showed that operating cost and interest rate have a negative impact on profitability where as Gross domestic product, Inflation and size have a positive impact on profitability. This implies that the profitability of Nepal Oil Corporation depends on macroeconomic factors and microeconomic factors. The positive relationship between gross domestic product and profitability is in line with theory. Thus government policies on employment and investments should be intensified to increase the profitability of Oil Corporation. Inflation seemed to have been a positive influence on profitability; high inflation may generally be undesirable. The result suggests that probably the managers are accurately predicting inflation and are able to adjust their lending rates accordingly. Low inflationary regimes create stable economy and a congenial investment climate for business, enabling businesses to pursue long term project critical to their survival and growth.
\end{abstract}

\section{KEY WORDS}

Gross Domestic Product, Inflation, Interest Rate, Size, Operating Cost, Return on Assets

\section{INTRODUCTION}

Oil Corporation performs key functions in economy such as providing a payment mechanism, matching supply and demand, providing markets transparency, performing risk transfer and risk management functions. Therefore, Oil Corporation plays a crucial role in the operation of economy. During the last decades, the oil corporation all around the world has experienced Vol. 2. No. II 
ISSN: 2362-1303 (Paper) | eISSN: 2362-1311(Online)

JOURNAL OF ADVANCED ACADEMIC RESEARCH (JAAR)

July 2015

some profound changes, as innovations in technology and the predictable forces driving globalization which creates both opportunities for growth and challenges for Oil Corporation to remain profitable in this increasingly competitive environment. These major transformations in environment, resulting in significant impacts on its performance.

The profitability of Oil Corporation is of great importance on its future operating activities. The financial performance of any institution cannot be found without analyzing its financial statements. Financial statements play a major role in a fundamental approach to security analysis. Among the items of potential interest to the analysis, financial ratios are the key parts of financial statements. The first thing to know about the financial performance is the profitability before turning to the debt and liquidity analysis. The ability of financial institutions is to produce dividends and capital gains in the future is what gives stock its value. The ability to make timely interest payments does not compare with the ability of a firm to be profitable. However, once the firm's profitability has been assessed, then financial institutions can meet their current and future obligations (Haim and Post, 2005).

Profitability is the primary goal of all business ventures. Without profitability the business will not survive in the long run. So measuring current and past profitability is very important. Profitability is measured by income and expenses. Income is generated from the activities of the business. A business that is highly profitable has the ability to reward its owners with a large return on investment (Waweru\&Kalani, 2009).

Profitability is necessary for Oil Corporation to maintain ongoing activity and for its shareholders to obtain fair returns. Thereby, both external and internal factors have been affecting the profitability of Oil Corporation over time. Internal factors of Oil Corporation profitability can be defined as factors that are influenced by a Corporation's management decisions. Such management effects will definitely affect the operating results of Corporation. External determinants of profitability are factors that are beyond the control of a management. They represent events outside the influence of the Corporation. Therefore, the determinants of Oil Corporation performance have attracted the interest of academic research as well as of Oil Corporation management and government regulators. Thus, research on the Oil Corporation system and profitability has been important for policy implications, which makes it interesting to study.

Operating costs of a Corporation as a percentage of its profits are expected to have a negative correlation with profitability. The level of operating expenses is viewed as an indicator of the management's efficiency. Pasiouras and Kosmidou (2007) in their study of European Union countries conclude that operating costs have a negative effect on profit measures. The inclusion 
ISSN: 2362-1303 (Paper) | eISSN: 2362-1311(Online)

JOURNAL OF ADVANCED ACADEMIC RESEARCH (JAAR)

July 2015

of Corporation expenses into the profitability is also supported by Bourke (1989) and Molyneux and Thorton (1992) who find a link between profitability and expense management.

Another group of variables impacting profitability are macroeconomic control variables such as gross domestic product, interest rates and inflation. Gross domestic product is one of the most common measures of the total economic activity within a country. The growth of gross domestic product has significant positive effect on the profitability of the financial sector. Inflation is often cited to be a significant determinant of bank profitability. Among studies that find a significant positive relationship between inflation and bank earnings are those conducted by Molyneux and Thorton (1992) and Bourke (1989).Flamini et al (2009) noted that if high returns are the consequence of market power, this implies some degree of inefficiency in the provision of financial services. According to Staikouras and Wood (2003), macroeconomic indicators such as variability of interest rate, growth of gross domestic product had a negative impact on profitability.

Despite these profound studies on profitability, a review of empirical research had been done to analyze the determinants of profitability of Nepal Oil Corporation and this is the gap in which this study intended to fill. The concern of this study therefore was to identify the macro economic factors and micro economic factors affecting performance in Nepal Oil Corporation. The study is of utmost relevance as it addresses what are the determinants of profitability and the findings would serve as the basis to provide policy measures to the various stakeholders on which factor to focus to tackle the effect of profitability. Relating with the various issues to the determinants of profitability, a number of research questions are raised: What are the internal and external factors of profitability of Nepal Oil Corporation?Does operating cost affect the profitability of Nepal Oil Corporation?

The main objective of the study was to examine the determinants of profitability of Nepal oil Corporation.

In literature, the determinants of profitability are empirically well explored although the definition of profitability varies among studies. Thereby, the bank profitability, typically measured by the return on assets (ROA) and/or the return on equity after tax (ROE), is usually expressed as a function of internal and external determinants. The majority of studies on profitability, such as Short (1979), Bourke (1989), Molyneux and Thornton (1992), DemirgucKunt and Huizinga (2000) and Goddard et al. (2004), use linear models to estimate the impact of various factors that may be important in explaining profits. Short (1979) and Bourke (1989) provided the first studies on bank profitability. Some subsequent studies aimed at explaining bank profitability in a single country were done by Guru et al. (1999), Naceur (2003), Athanasoglou et al. (2005), Kosmidou (2006), Vong and Chan (2006), Garcia-Herrero et al. (2007), Ramlall (2009), Davydenko (2010).

Vol. 2. No. II

www.phdcentre.edu.np 
ISSN: 2362-1303 (Paper) | eISSN: 2362-1311(Online)

JOURNAL OF ADVANCED ACADEMIC RESEARCH (JAAR)

July 2015

Other studies aim at analyzing profitability in groups of countries: Molyneux and Thorton (1992) were the first to investigate a multi-country setting by examining the determinants of bank profitability for a panel of European countries, followed by Staikouras and Wood (2003), analyze the performance of a sample of banks operating in 13 European countries and Pasiouras and Kosmidou (2007) who studied the factors influencing the profitability of domestic and foreign banks in the European Union. Other multi-country studies include Demirguc-Kunt and Huizinga (1999) investigate the determinants of bank interest margins using bank-level data for 80 countries in the years by consider a comprehensive set of bank specific characteristics, as well as macroeconomic conditions, taxation, regulations, financial structure and legal indicators. Goddard et al. (2004) used panel and cross-sectional regressions to estimate growth and profit models for a sample of almost 600 banks from five European Union countries over the period 1992-1998. Flamini et al. (2009) have used a sample of 389 banks in 41 Sub-Saharan Africa countries to study the determinants of bank profitability.

There are common factors/determinants influencing profitability identified by several researchers such as cost, size, capital, risks as internal factors/Bank-specific determinants. Size is generally used to capture potential economies or diseconomies of scale in the Corporation sector. This variable controls for cost differences and product and risk diversification according to the size of the credit institution. The impact of a size on its profitability is not uniform. Short (1979) goes further by claiming that size has a positive influence on profitability through lowering the cost of raising capital for big Corporation. Later, studies by Flamini et al. (2009) support the proposition that increasing a Corporation's size positively affects profitability and actively diversification by private ownership. However, there is no consensus in the literature on whether an increase in size provides economies of scale to banks. Operating costs of a Corporation as a percentage of its profits are expected to have a negative correlation with profitability. In the literature, the level of operating expenses is viewed as an indicator of the management's efficiency. The inclusion of expenses into the profitability is also supported by Bourke (1989) and Molyneux and Thorton (1992) who find a link between profitability and expense management. Various studies suggest that Corporation with higher levels of capital perform better than their undercapitalized peers.

Macroeconomic determinants impacting profitability are macroeconomic control variables such as gross domestic product, interest rates and inflation. gross domestic product is one of the most common measures of the total economic activity within a country. The growth of gross domestic product has significant positive effect on the profitability of the financial sector. Inflation is often cited to be a significant determinant of profitability. Among studies that find a significant positive relationship between inflation and earnings are those conducted by Molyneux and Thorton (1992) and Bourke (1989).Flamini et al (2009) noted that if high returns 
ISSN: 2362-1303 (Paper) | eISSN: 2362-1311(Online)

JOURNAL OF ADVANCED ACADEMIC RESEARCH (JAAR)

July 2015

are the consequence of market power, this implies some degree of inefficiency in the provision of financial services. According to Staikouras and Wood (2003), macroeconomic indicators such as variability of interest rate, growth of gross domestic product had a negative impact on profitability.

\section{METHOD}

This study adopts descriptive and causal comparative research designs to deal with the fundamental issues associated with the impact of bank specific and macro-economic variables on profitability of Nepal Oil Corporation. The descriptive research design will be adopted for fact-finding and gathering adequate information about bank specific and macro-economic factors affecting profitability. Besides, an effort is made to describe the nature of pooled profitability of Nepal Oil Corporation during 2004 to 2014 using descriptive statistics with respect to firm specific and macro-economic variables This study is also based on causal comparative research design to ascertain and understand the directions, magnitudes and forms of observed relationship of determinants of profitability of Nepal Oil Corporation.

Based on the brief literature review on the determinants of profitability of the Nepal Oil Corporation are influenced by several variables and among them bank specific, macroeconomic are found to be important ones. The bank specific data consist of yearly observations of return on assets, return on equity, size, and operating cost. Nepal Oil Corporation publishes various reports including profit and loss account, income statement and balance-sheet of the Nepal Oil Corporation. The necessary data related to bank specific variables are collected from these reports. Other data related to macro-economic variables are collected from economic survey published by ministry of finance, Government of Nepal. Financial structure related variables are collected from the financial statements of the banks and economic survey and necessary calculation will also be made. The study is based on the pooled OLS of Nepal Oil Corporation.

The method of secondary data analysis in this study consists of econometric models including several statistical tests of significance. Econometrics model consists of pooled OLS. The study has also used descriptive statistics, correlation analysis and the statistical tests. The details of models and statistical test of significance have been presented in the following sections.

In this study, econometrics models are used to describe the various components of profitability of Nepal Oil Corporation. Pooled OLS was used to measure various component of profitability. This study uses profitability as the dependent variable and gross domestic product, inflation, interest rate, size, management efficiency, capital ratio, is taken as independent variables. This basic test is used in this to regress dependent variable against independent variables.

\section{Specification of the Model}

Vol. 2. No. II

www.phdcentre.edu.np 
ISSN: 2362-1303 (Paper) | eISSN: 2362-1311(Online)

The following models are used to examine the association between the independent and dependent variables of Nepal Oil Corporation.

Profitability $_{i t}=\beta 0+\beta_{1}$ GROSS DOMESTIC PRODUCT $i t+\beta_{2} \mathrm{INF}_{\mathrm{it}}+\beta_{3} \mathrm{IR}_{\mathrm{it}}+\beta_{4} \mathrm{LNTA}_{\mathrm{it}}+$ $\beta_{5} \mathrm{OC}_{\mathrm{it}}+\mathrm{e}_{\mathrm{it}}$

\section{RESULT AND DISCUSSIONS}

As this study has employed descriptive research design, among others, descriptive statistics have been used to describe the determinants of profitability during the study period. The descriptive statistics used in this study consists of mean, standard deviation, and minimum and maximum values associated with variables under consideration. Table 1 summarizes the descriptive statistics of macroeconomic and microeconomic variables used in this study.

\begin{tabular}{|c|c|c|c|c|c|c|c|}
\hline \multicolumn{7}{|c|}{ Table 1: Descriptive statistic of determinants of profitability } \\
\hline \multirow{2}{*}{$\mathrm{N}$} & & GDP & INF & IR & LNTA & OC & ROA \\
\cline { 2 - 9 } & & 11 & 11 & 11 & 11 & 11 & 11 \\
\hline \multicolumn{2}{|c|}{ Mean } & 4.3527 & 7.75 & 3.6427 & 22.4336 & 39.5173 & -6.8064 \\
\hline \multicolumn{2}{|c|}{ Std. Deviation } & 1.02039 & 2.479 & 2.50462 & .32091 & 7.41871 & 2.50376 \\
\hline \multicolumn{2}{|c|}{ Minimum } & 3.00 & 4 & 1.28 & 21.81 & 31.57 & -42.21 \\
\hline \multicolumn{2}{|c|}{ Maximum } & 6.10 & 13 & 8.44 & 22.91 & 55.02 & 22.24 \\
\hline
\end{tabular}

Note. Table 1presents the descriptive statistics - mean, minimum, maximum, and standard deviation of microeconomic and macro-economic for the period of 2004-2014. All figures are in percentage term.

Return on asset has mean value of -6.80 , which is lowest as compared to that of other variables. The standard deviation 2.50 and range 3.10 showed that there was lowest variability in the data for the profitability measures. The bank size plays an important role to maintain the position of a bank in the market. The size of Nepal Oil Corporation under this study has mean value of 22.43, and the maximum and minimum value of 22.91 and 21.81 respectively. But the standard deviation value is 0.32 which show that Oil Corporation in Nepal have a small variation in their total asset. Similarly the macroeconomic variables GROSS DOMESTIC PRODUCT, inflation and interbank rate also raises from minimum 3,4 and 1.28 to maximum $6.10,13$ and 8.44 with a mean value of 4.35, 7.75 and 3.64 and standard deviation of 1.02, 2.4 and 2.5 respectively.

The correlation of the different variables used in this study also has been calculated and presented in this section. This section therefore is devoted to explaining the direction and magnitude of relationship among different pairs of these variables including. Table 2 presents Vol. 2. No. II 
ISSN: 2362-1303 (Paper) | eISSN: 2362-1311(Online)

JOURNAL OF ADVANCED ACADEMIC RESEARCH (JAAR)

the value of bivariate Pearson correlation coefficient between different pairs of variables of sample firm during the period 2004/05 through 2014/15.

Table 2: Correlartion Coefficient of Determinants of Profitability

\begin{tabular}{|c|c|c|c|c|c|c|}
\hline & GDP & INF & IR & LNTA & OC & ROA \\
\hline GDP & 1 & & & & & \\
\hline INF & 0.244 & 1 & & & & \\
\hline IR & 0.222 & 0.38 & 1 & & & \\
\hline LNTA & 0.21 & 0.51 & -0.17 & 1 & & \\
\hline OC & -0.275 & -0.338 & 0.11 & 0.59 & 1 & \\
\hline ROA & 0.22 & 0.54 & -0.15 & $0.86^{\prime}$, & $-0.799^{\prime}$ & 1 \\
\hline $\begin{array}{l}\text { ** Correlation is significant at } 0.01 \text { level (two tailed). *Correlation is significant at } 0.01 \text { level (two tailed) } \\
\text { Note. Table 2 presents bi-variate Pearson correlation coefficients among different microeconomic and macro- } \\
\text { economic variables. ROA refers to return on assets, size stands for log of total assets, Similarly, GDP presents } \\
\text { annual growth of gross domestic production, INF is inflation, and IR refers to interest rate. }\end{array}$ \\
\hline
\end{tabular}

From the table above, there was a positive correlation between return on assets GROSS DOMESTIC PRODUCT, INF and IR and size whereas, there is negative correlation between interest rate and return on assets and operating cost and return on assets. The highest correlation of the independent variables to ROA is observed to be of size $(r=0.86)$ in context to Nepal Oil Corporation while as lowest strength is of ROA and IR $(r=-0.15)$.

Table No:3: Regression Results of Determinants of Profitability

\begin{tabular}{|c|c|c|c|c|c|c|}
\hline & \multirow{2}{*}{ Model } & \multicolumn{2}{|c|}{$\begin{array}{l}\text { Unstandardized } \\
\text { Coefficients }\end{array}$} & \multirow{2}{*}{$\begin{array}{c}\text { Standardized } \\
\text { Coefficients }\end{array}$} & \multirow[t]{2}{*}{$\mathrm{t}$} & \multirow{2}{*}{ Sig. } \\
\hline & & $\mathrm{B}$ & Std. Error & & & \\
\hline \multirow{6}{*}{1} & (Constant) & -847.048 & 390.292 & & -2.170 & .082 \\
\hline & Gross Domestic Product & -.736 & 3.966 & -.030 & -.186 & .860 \\
\hline & INF & 1.800 & 2.105 & .178 & .855 & .432 \\
\hline & IR & -.832 & 1.868 & -.083 & -.446 & 674 \\
\hline & LNTA & 39.691 & 17.171 & .509 & 2.312 & .069 \\
\hline & $\mathrm{OC}$ & -1.464 & .639 & -.434 & -2.292 & .071 \\
\hline \multicolumn{3}{|c|}{ a. Dependent Variable: ROA } & & & & \\
\hline
\end{tabular}

The coefficient of Size is positively related to ROA with an estimate of 39.69 this implies that an increase in size of a Oil Corporation leads to an increase in ROA by 39.69units. Operating cost shows an inverse relationship with ROA having a negative coefficient of -1.46 , this mean 
ISSN: 2362-1303 (Paper) | eISSN: 2362-1311(Online)

JOURNAL OF ADVANCED ACADEMIC RESEARCH (JAAR)

July 2015

that an increase in the level of operating cost of the oil corporation lead to decrease in ROA. Macroeconomic variables INF have a positive impact on profitability. This implies that an increase in economic growth, increase in inflation of a country leads to increase in both profitability measures.

\section{CONCLUSION}

This study empirically examined the determinants of profitability by NepalOil Corporation over 2004 to 2014 periods. This study takes its importance from the numerous structural changes in the Oil Corporation of Nepal that have exposed them to a number of risks and stated important challenges for their stability.

Changes in economic policies, political changes and the goals of leading political parties also influence the range of the investment credit. The preceding regression results allow shedding some light on the key factor affecting profitability. The findings show that size, GROSS DOMESTIC PRODUCT and INF have significant influence on profitability and operating cost and IR were not significant with the profitability.

1. A healthy economy is a prerequisite for healthy system. Hence the positive relationship between GROSS DOMESTIC PRODUCT and profitability is in line with theory. Thus government policies on employment and investments should be intensified to increase the profitability of Oil Corporation.

2. Although inflation seemed to have a positive influence on profitability, high inflation may generally be undesirable. The result suggests that probably, managers are accurately predicting inflation and are able to adjust their lending rates accordingly. Low inflationary regimes create stable economy and a congenial investment climate for business, enabling businesses to pursue long term project critical to their survival and growth.

3. In context of Nepal, data scarcity is acute. Updated and complete data are limited due to the manual securities data management system prevailing in the country.

\section{ACKNOWLEDGEMENT}

I am grateful to the Prof. Dr. Radhe Shyam Pradhan for his regular support and guidance to me. I would also like to express my sincere thanks to Dr. Tatwa P. Timilsina and Mr. Tej Bahadur Karki and other team members of $\mathrm{PhD}$ centre, Kathmandu for expected encouragement. I also thank to Director Mr. NagendraSah who provides me a data of Nepal oil Corporation. I would also like to thank Mr. Jeet Bajracharya (Program Director of Mega National College, Lalitpur) for his kind support. And I would like to thank to my wife Mrs. Priya Shah who encourages me and support in my research works.

\section{REFERENCE}


ISSN: 2362-1303 (Paper) | eISSN: 2362-1311(Online)

JOURNAL OF ADVANCED ACADEMIC RESEARCH (JAAR)

July 2015

Al-Smadi, M. O. M. (2010). Credit risk, macroeconomic and bank specific factors in Jordanian banks. PhD Thesis, Universiti Utara Malaysia.

Angbazo, L. (1997). Commercial bank net interest margins, default risk, interest-rate risk, and off-balance sheet banking. Journal of Banking \& Finance, 21(1), 55-87.

Aver, B. (2008). "An empirical analysis of credit risk factors of the Slovenian banking system."Managing Global Transitions 6(3): 317-334.

Basel. (1999). Principles for the management of credit risk Conductive paper issued by Basel Committee on Banking Supervision, Basel.

Basel Committee on banking Supervision (2001): "Risk Management Practices and Regulatory Capital: Cross-sectional Comparison". Basel Committee on Banking Supervision.

Boudriga, A., Boulila, N., \&Jellouli, S. (2009). Does Bank Supervision Impact Nonperforming Loans: Cross Country Determinants Using Aggregate Data. Journal of Banking \& Finance, 25(1), 47-95.

Brownbridge Martin, (1998): Implications for Prudential Policy: Discussion Paper, in Local Banks in Africa No. 132

Casu, B., Girardone, C. and Molyneux, P., 2006. Introduction to Banking. Harlow: Pearson.

Credit Issue, 1997. Credit Risk+: A Credit Risk Management Framework. Credit Issue Financial Products.

Chijoriga, M. M. (1997). Application of Credit Scoring and Financial Distress Prediction Models to Commercial Banks Lending: The Case of Tanzania. Ph.D Dissertation, WirtsChaftsnnversitat Wien (WU), Vienna.

Coyle, B. (2000). Framework for Credit Risk Management; Chartered Institute of Bankers, United Kingdom.

Dahal, B. (2009). "Experience of the Nepalese Commercial Banks and Challenge Ahead : Nepalese Financial System : Growth and Challenges." Special publication by Nepal Rastra Bank (Central Bank), Nepal: 50-63.

Das, A. and S. Ghosh (2007). "Determinants of Credit Risk in Indian State-owned Banks: An Empirical Investigation." Economic Issues-Stoke on Trent 12 (2): 27-46.

Demirguc-Kunt, A \&Detragiache, E (2000), "Monitoring banking sector fragility: a multivariate logit approach", World Bank Economic Review, Oxford University Press, vol. 14, no. 2, pp. 287-307.

Selma.M. Ahlem and JouiniFathi (2013): Micro and Micro determinants of Nonperforming; Tunisia, International Journal of Economics and Financial Issues. Vol.3, No.4, pp 852-860

Shingjerji Ali (2013): Impact of Bank Specific Variables on the Nonperforming loans ratio in Albanian Banking System, Journal of Finance and Accounting: Vol.4, No.7.

Sinkey J. (1992); Commercial Bank Financial Management, Mcmillan Publishing company, New York 
ISSN: 2362-1303 (Paper) | eISSN: 2362-1311(Online)

JOURNAL OF ADVANCED ACADEMIC RESEARCH (JAAR) July 2015

Sufian, F., and Habibullah, M.S., (2009), " Determinants of bank profitability in a developing economy: Empirical evidence from the Bangladesh. ."Journal of Business Economics and Management, Vol.10, No. $3: 2007-2017$.

SwamyVighneswara (2012): Impact of Macroeconomic and Endogenous Factors on Nonperforming Bank Assets: International Journal of Banking and Finance, Vol. 9.

Thiagarajan, S., S. Auuapan, et al. (2011)."Credit risk determinants of public and private sector banks in India." European Journal of Economics, Finance and Administrative Science(34): 147-154.

TomakSerpil(2013) Determinants of Commercial Banks 'lending Behavior: Evidence From Turkey: Journal Of Empirical Research, 3(8):933-943.

Wanjira, L. T. (2010) "The relationship between non- performing loans management practices and financial performance of commercial banks in Kenya, unpublished MBA project, University of Nairobi.

ZewduSeyoum(2010): Impact of reducing loan by Ethiopian banks on their own performance; published thesis (MSc), University of South Africa 